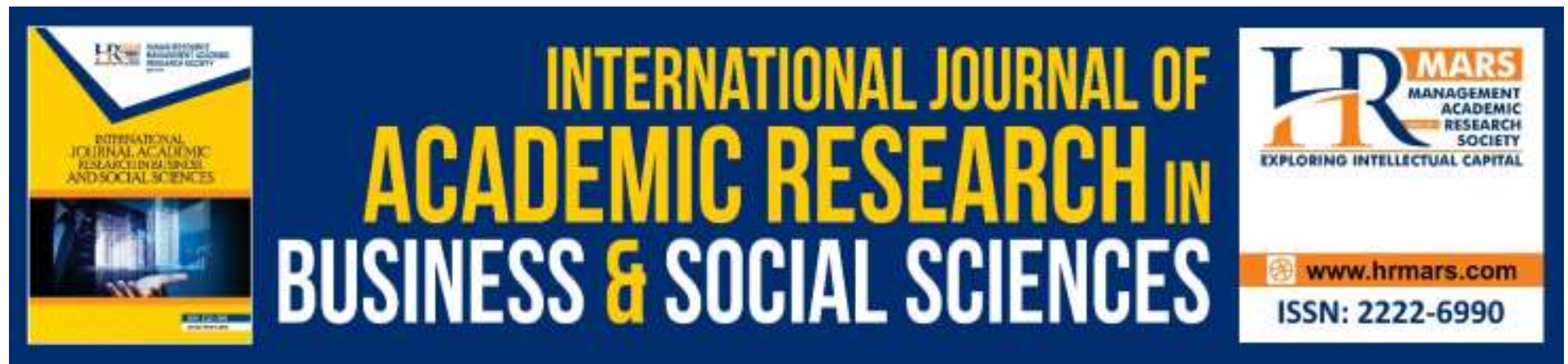

\title{
Students' Cognitive Ability and Attitude Towards Stress
}

\section{Jerald C Moneva, Dave Michael D. Ramos, Richard F. Ruelan and Wilfe T. Besin}

To Link this Article: http://dx.doi.org/10.6007/IJARBSS/v10-i4/7135

DOI:10.6007/IJARBSS/v10-i4/7135

Received: 24 February 2020, Revised: 20 March 2020, Accepted: 28 March 2020

Published Online: 19 April 2020

In-Text Citation: (Moneva et al., 2020)

To Cite this Article: Moneva, J. C., Ramos, D. M. D., Ruelan, R. F., \& Besin, W. T. (2020). Students' Cognitive Ability and Attitude Towards Stress. International Journal of Academic Research in Business and Social Science, 10(4), 318-335.

\section{Copyright: (C) 2020 The Author(s)}

Published by Human Resource Management Academic Research Society (www.hrmars.com)

This article is published under the Creative Commons Attribution (CC BY 4.0) license. Anyone may reproduce, distribute, translate and create derivative works of this article (for both commercial and non-commercial purposes), subject to full attribution to the original publication and authors. The full terms of this license may be seen

at: http://creativecommons.org/licences/by/4.0/legalcode

Vol. 10, No. 4, 2020, Pg. 318 - 335

http://hrmars.com/index.php/pages/detail/IJARBSS

JOURNAL HOMEPAGE

Full Terms \& Conditions of access and use can be found at http://hrmars.com/index.php/pages/detail/publication-ethics 


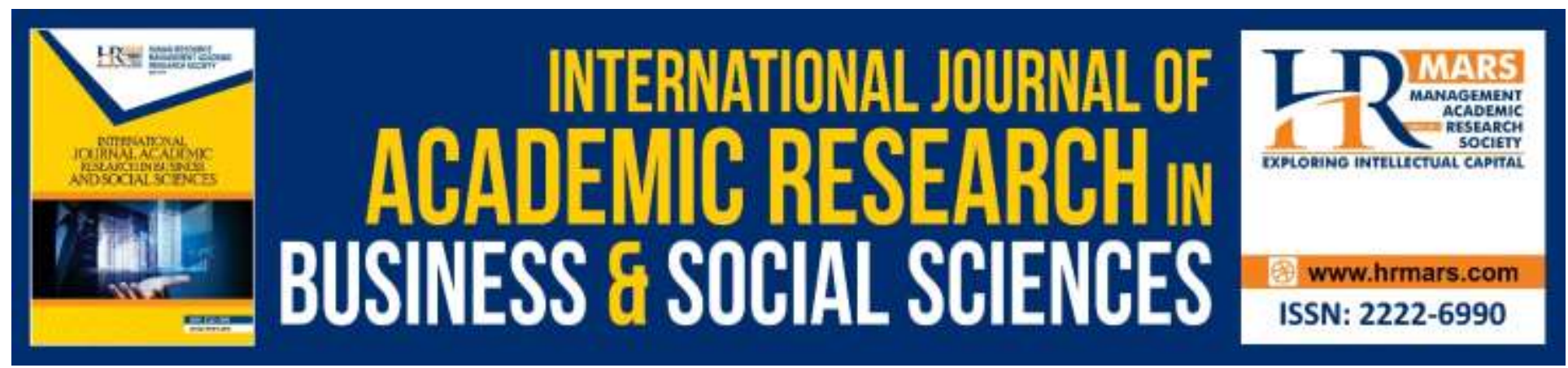

\title{
Students' Cognitive Ability and Attitude Towards Stress
}

\author{
Jerald C Moneva, Dave Michael D. Ramos, Richard F. Ruelan, \\ and Wilfe T. Besin
}

Jagobiao Nation High School, North Road, Jagobiao, Mandaue City, Philippines

\begin{abstract}
Stress is inevitable and universal. Cognitive ability is essential in coping stress with the support of the attitude towards stress. The purpose of this study was to determine the students' cognitive ability and attitude towards stress. The researchers used quantitative approach, descriptive survey research design that consisted of two self-base questionnaire. The researchers conducted and gathered data at Jagobiao National High School-Senior High department, all senior high students. The data have been analyzed using chi-square to determine the association between the students' cognitive ability and attitude towards stress. The results is failed to reject the null hypothesis. Thus, the study revealed that there was no association between the students' cognitive ability and attitude towards stress. Based on the findings, cognitive ability helps to coped stress in engage tress management solutions to the problems and situations but the attitude doesn't help to the cognitive ability but only support to the students' emotional aspect in order to handle the difficulties of the stress.
\end{abstract}

Keywords: Cognitive Ability, Attitude, Stress, Stress Management.

\section{Introduction}

Stress is one of the problems of people especially the students. With stress, students cannot focus in their studies and became more passive in many activities in school. Stress can affect the students' health such as body pain, illness, fatigues, and in severe cases can also lead to death. Stress also affects the students' credibility of thinking, behavior, attitudes, perspectives, physical changes, and appropriate way of dealing the situations and problems. Students usually involved their capacity of managing stress in dealing problems and situations that result into stress. Students' capability of managing stress determines that they have a good and holistic thinking in dealing a difficult situations and problems.

As observed by the researchers, Jagobiao National High School particularly the Senior High School students were experiencing stress. Both grade 11 and grade 12 Senior High students are experiencing stress because they were experiencing greater responsibilities and expectations from the teachers and parents which lead to the implication of pressure. There is also a possibility 
that the grade 12 and grade 11 students were affected in the stage of heading to adolescence to early adulthood, students need to adopt and change the pace they usually do. The students in Jagobiao National High School-Senior High have different understanding, learning, and idea to resolve a particular situation or problem. For an instance, a student who has a low academic performance can rather easily tackle some difficulties. It doesn't mean that when a student has a high academic performance is also good in dealing with some certain difficulties. It depends on how each student understood and visualized the situation to arrive at a solution. Even they have different approach in solving a problem or situation, they still have similarities. Dealing a stress, a particular knowledge, idea, learning, and experience are needed in order to solve the problems or situations. In addition, cognitive ability such as verbal ability, mathematical ability, and scientific ability can help the students cope the situation. The verbal, scientific, and mathematical ability are just some abilities of cognitive that determines the growth and development of students through better understand these abilities. General cognitive ability and cognitive aptitude such as inductive reasoning, spatial, and verbal abilities has a significant connection to the computational thinking but in a lesser extent (Roman-Gonzales, Perez-Gonzales and JimenezFernandez, 2016).The Senior High grade 12 and grade 11 students have a high responsibilities and expectations leading them to a stressful condition. In connection to this, looking into the cognitive ability of the students can help other people to understand students better. Thus, it is worthwhile to indicate of the association between attitude of students towards stress and cognitive ability.

Individuals are at different risks in experiencing stress where more likely to experience in lacking of materials and psychological resources affecting also their emotional reactions (Michie, 2002). Usually the student's reason of having stress is psychological and adequacy of resources creating pressure, pressure implicates their emotional, mental, physical, and spiritual aspect. But as long as the students are capable of dealing and understanding the situations, they are expected to overcome the stress. Effective management and views on the situations of the students, can teach students to determine their stressors and overcome them. Students' cognitive ability can be implicated on stress in a particular situation.

The students' conscious mental activities such as activities of thinking, understanding, learning, and remembering, are part of dealing a situation particularly stress. The cognitive maturation occurs simultaneously during childhood and adolescence as well as the brain development (Casey, Tottenhem, and Durston, 2005). By improving decision-making accuracy can help students to understand more about the nature and development of cognitive ability (Kuncel and Hezlett, 2012). Managing stress allow the students to generate ideas and establish possible and effective solutions in problems. In relation to this, researchers intend to assess the relationship of the cognitive ability of the students towards their attitude towards stress.

\section{Theoretical Background}

Social cognitive theory of self-regulation theorized by Albert Bandura in 1991 stated that pre-existing cognitive ability structures and self-beliefs exert particular influence on the aspects of one's functioning as given the most attention, how they are perceived, and how performance information, it was organized for memory presentation. Self-monitoring of behavior bears the personal competence and self-esteem, in turn, it activates affective reactions that can distort 
self-perceptions at the time of the behavior is occurring. The self-observation provides the information needed for setting realistic goals and evaluating one's progress. Systematic selfobservation can provide important self- diagnostic information (Bandura, 1991). For an instance, when people observe their thought patterns, emotional reactions, and behavior and the conditions under which these reactions occur, they begun to notice recurrent patterns. By analyzing regularities in the covariation between situations and their thoughts and actions, people can identify significant features of their social environment that lead them to behave in certain ways.

The social cognitive theory of self-regulation talked about how people exert or act on their self-monitoring, self-observation, and self-perception that are categorized by their selfregulation as part to their cognitive ability. The self-monitoring takes the personal competence and the self-esteem of a person. The self-perception activates the affective reactions and its behavior from a person. The self-observation provides the information needed for setting goals where it can provide important self-diagnostic information. The self-diagnostic information observes the thought patterns, emotional reactions, behavior, and conditions under the reaction occur to the person (Bandura, 1991). Through this 3 category of self-regulation, it can easily analyze the situations, the thoughts and actions in social environment. When the people perform their thoughts, ideas, knowledge, behavior and reactions, they begin to use their cognitive ability in order for them to exert their needed such as the self-observation, self-monitoring, and selfperception. The students usually involved in these patterns for their self-regulation. The students has an expectation to their cognitive ability to meet their self-regulation so that when they are having stress, it could be easier for them to solve the situations or problems because when they have a high self-regulation, it instantly understood that they had also a high self-perception, selfmonitoring, and self-observation.

In relation to this, the social cognitive theory of self-regulation supports the study of attitude of students in stress and students' cognitive ability. It conveys that in relation to the students' cognitive ability, it specialize the self-regulation that was categorized into 3: selfperception, self-monitoring, and self-observation. It's part of the students in dealing the situations or problems that result into stress. The self-monitoring that takes personal competence and self-esteem can help the students to have self-esteem in dealing stress. The self-perception that activates affective behavior can help the students to determine their behavior in dealing stress. And the self-observation that provides setting goals can help students to have a high determination and persistence to reach a particular tasks or goals they want to achieve.

\section{Statement of Purpose}

The study intends to assess the students' cognitive ability and attitude towards stress. Specifically, the study seeks to answer the following sub-problems:

1. To what degree can students manage their stress?

2. What is the level of cognitive ability of the students?

3. Is there an association between the students' cognitive ability and attitude towards stress? 


\section{Hypothesis}

Null Hypothesis ( $\mathrm{HO})$ :

There is no significant relationship between the students' cognitive ability and attitude towards stress.

Alternative Hypothesis (H1):

There is a significant relationship between the students' cognitive ability and attitude towards stress.

\section{Significance of the Study}

The researcher study titled "students' cognitive ability and attitude towards stress" can be beneficial to the following:

The students are most beneficial to this study because it can give them information, awareness, ideas, knowledge, techniques, and methods about their attitude towards stress and their cognitive ability.

The teachers shall get benefits from this study because the findings, conclusions, and interpretation to the study could help them to guide and create ideas about to their students' cognitive ability and attitude towards stress.

The parents shall get benefits from the study because it will serve as guidance and awareness for their children about the cognitive ability and attitude towards stress. The parents can also create an ideas and methods to lessen or prevent the stress of their children.

The future researchers shall benefits to this study because it will set as their references and guidance for their further research.

The school head shall get benefits from the study because it can give information and possible solutions for the students' cognitive ability and attitude towards stress

\section{Review of Related Literature}

In this chapter, the related studies and articles are found in this placed. This related articles and studies will serve to give the researcher further knowledge of the study "Students' Cognitive Ability and Attitude towards Stress".

\section{Students' Cognitive Ability and Attitude towards Stress}

The individual needs a support and resources to enhance their cognitive ability in able to access a better environment (Rindermann, 2012). There is a mutual connection between the cognitive and non-cognitive where it both determines the achievement (Chiese and Primi, 2010). Students have a fear in relating of insecurities about their professional future, while there are still no bases that the strategies and platforms offers from universities and schools are effective in dealing the stress of the students (Murphy, Gray, Sterling, Reeves and DuCette, 2008). Students experiencing stress is related to its level of depressive symptoms when it has inability to cope up even in a low level of stress where it could weaken their development of resilience and having a vulnerability of depression (Sawatzky, Ratner, Richardson, Washbum, Sudmant and Mirwaldt, 2012). Individuals are different in experiencing stress and unfavorable effect of stress. Lacking of 
material resources and psychological resources can give a harmful effect to them if they react emotionally and pressured in the environment (Michie, 2002).

Cognitive ability

As the brain development change in a progressive and regressive way, the cognitive maturation also happening at the same time during childhood and adolescence stage where the maturation process reflects the experience and development of a person (Casey, Tottenham, Liston and Durston, 2005). When the students are hardworking, responsible, dutifulness, and achievement-oriented it has a positive affects into their academic success (Furnha, ChamorroPremuzic and McDougall, 2003). The personality trait conscientiousness appeared to be a positive predictor for academic success where the academic success of the student has a relationship with intellectual ability and achievement motivation.(Busato, Prins, Elshout and Hamaker, 2000). Cognitive ability is essential for success in any field and everyone has a potential to improve in any cognitive area (Halpern, 2004). The computational thinking has a significant connection to the general cognitive ability, also with specific cognitive aptitude such as inductive reasoning, spatial, and verbal abilities but in a lesser extent (Roman-Gonzales, Perez-Gonzales and Jimenez-Fernandez, 2016).

Cognitive ability has a major role especially in predicting prejudice because it can provide a framework on mental abilities, emotions, and motivations that can support for understanding how prejudice and social-cultural ideologies developed in individuals (Hodson and Busseri, 2012). The common component of test mental ability which is the general factor consistently tapped even very distinct tests of mental ability (Koenig, Frey and Detterman, 2008). The authoritative parenting practice has a positive influence for the cognitive ability to their children than being a permissive and authoritarian parenting practice (Rudasill, Adelson, Callahan, Houlihan and Keizer, 2013). The children from their wealthy peers had expands the differences of their cognitive (Ready, 2010). Furthermore, the cognitive ability is very important in sustaining and creating a high-achievement milieu leading to economic growth and wealth, and democratic and free society (Rindermann and Thompson, 2011). There are test across academic and work settings which is a strong performance predictor, but there's one for deeper understanding on the cognitive abilities development and assessing more the cognitive ability test (Kunceland Hezlett, 2010).

Attitude towards stress

Coping stress manage describe the thoughts and behavior that are used to manage the internal and external needed or demands of the situations (Goodhand and Rampton, 2008). The effect of self-leadership and emotion regulation strategies in coping stress was centralized by the positive affect and self-efficacy (Houghton, Wu, Godwin, Neck and Manz, 2012). The individual has a huge difference in cognitive ability as well as to their domains of talent development. These differences draw their different strategies and different intellectual strengths to accomplish their task (Lubinski, 2009). Therefore, when an individual is coping with stress, various coping strategies are used which depends upon the situation, the interaction between the person and situational factors, and the personality of the individual (DeLongis and Holtzman, 2005).

It has direct experience and positive outcomes in using the behavioral stress management skills by engaging the students a point of readiness (Redwood and Pollak, 2007). Stress management could enhance the coping skills in dealing with stress outcomes without attempting 
to reduce or remove stressors (Giga, Cooper and Faragher, 2003). Also, it is effective in preventing inappropriate behavior that may lead to diseases and disorders such as smoking, unhealthy eating habits, and sedentary lifestyle (Varvogli and Darviri, 2011). To have positive mood and lower level of stress, it is better to employ daily mental training (Haraldsson, Lindgren, Fridlund, Baigi, Lydell and Marklund, 2008). After stressor exposure, state anxiety may lessen through listening to classical and self-selected music (Labbe, Schmidt, Babin and Pharr, 2007).

The E-learning can provide opportunities to the wide audience by delivering effective, evidenced-based, and stress and depression management strategies (Williams, Gatien and Hagerty, 2011). The digital age is related to the logical or content of such tool leading to comparison patterns of cognitive ability such as learn, acquire and develop complex set of skills (Campello de Souza, Xavier de Lima e Silva and Roazzi, 2010). In disseminating stress management resources, Facebook as online format is effective, intuitive, and efficient medium (George, Dellasega, Whitehead and Bordon, 2013). Women and men are facing an equal life events and experiences in stress, women's coping strategies are more in passive and emotionfocused behaviors while men are in active and instrumental coping behaviors (Matud, 2004). Having of high sense of humor has positive outcomes between number of everyday problem and cognitive appraisal regardless of stress (Abel, 2002).

Insight

Cognitive ability appears to be responsible in any part of a person how to think, understand, analyze, interpret, evaluate, and recognize. Some researchers' conclusion from their studies supports in many field of human interaction. Researchers also found out that the cognitive ability is a natural ability of a person. It is already a nature a person to understand and think without learning it from others. The cognitive ability develops and matures as the person experiences and learning new ideas and concept.

Stress is universal and inevitable. All persons experiencing stress daily. Every aspect in life has always a stress which results into difficulties of one person to handle it. The researchers found out that stress can be coped with stress management. Understanding the stress and its nature can help a person identify means of managing stress.

By further studies of some researchers, most factors that help to manage the stress is the persons conscious mental activity or also called as the cognitive ability of a person. The cognitive ability helps the person to evaluate, understand, and interpret the situations which caused the stress. There is a great impact of the cognitive ability in managing the stress. Further thorough understanding, there is a lot possibility that cognitive ability doesn't just help manage the stress but also helps grow and develop the person handle the stress.

\section{Research Methodology}

This section contains the research design, research environment, the research respondents, the instruments, data gathering procedure, and treatment of data. 
Design

The researchers used quantitative approach, descriptive survey research design. The researchers aimed to understand the relations between students' cognitive ability and attitude towards stress.

\section{Environment}

The researchers conducted the study in Jagobiao National High School-Senior High School department. The researchers focused on the grade 12 and grade 11 students from in different strands like grade 12 and grade 11 Accountancy, Business and Management (ABM), graded 12 and grade 11 Humanities and Social Science (HUMSS), grade 12 and grade 11 General Academic Strand (GAS), grade 11 Science Technology and Engineering Mathematics (STEM), and grade 11 Technical Vocational (TECHVOC).

\section{Respondents}

The students in Jagobiao National High School-Senior High grade 12 and grade11 students were selected by complete enumeration. There are 240 senior high students which is also the total respondents who answered from the questionnaire given from the researchers.

\section{Instrument}

The researchers made a questionnaire database that determines the capability of students from their cognitive ability. The questionnaire provided is answerable by using number $1,2,3$, and 4 that stands for (1) strongly disagree, (2) disagree, (3) agree, and (4) strongly agree. To support the cognitive ability questionnaire, the researchers also used NCAE results: verbal ability, scientific ability, and mathematical ability to understand further about the students' cognitive ability. The researchers make a questionnaire database that measures their attitude towards stress that are answerable by using number 1,2,3, and 4 that stands for (1) strongly disagree, (2) disagree, (3) agree, and (4) strongly agree.. This two instruments database could help to the researcher used for data analysis and interpretation.

\section{Data Gathering Procedure}

The researcher made a transmittal letter to ask permission from the students, teachers, and school head to conduct a survey. The researcher gathered during every vacant time of the students. The researchers gave the respondents or students a questionnaire to be gathered after 15 minutes analysis and interpretation. The researchers should finished gathering data in three weeks. The researchers also made a transmittal letter to ask permission from the teachers to get the NCAE results: Scientific ability, verbal ability, and mathematical ability of the grade 11 and grade 12 students to support the cognitive ability of the students.

\section{Statistical Treatment}

In interpreting and analysing the data, the researchers used the sum and mean, weighted mean, frequency and percentage, and chi-square for treat the data. Sum and mean used for computing the summation of scores to compute the weighted mean and the frequency of stress and cognitive ability. The overall weighted mean of each variable was used for chi-square to know 
the association between them. The frequency and percentage used to determine and identify which most respondent preferred from the choices given. And the chi-square was used to determine if there is association between the two variables.

\section{Presentation, Analysis, and Interpretation of Data}

This chapter discusses the presentation, analysis, and interpretation of data. Table 1 presents the results regarding the students' attitude towards stress and table 2 presents the frequency. Table 3 presents the results regarding the students' cognitive ability and the table 4 presents the frequency. And the table 5 presents the results regarding the association between the students' cognitive ability and attitude towards stress.

\section{TABLE 1}

\section{Students' Attitude towards Stress}

\begin{tabular}{llcc}
\hline & \multicolumn{1}{c}{ Indicator } & W. M. & Interpretation \\
\hline 1 & I couldn't seem to experience any positive feelings at all & 2.70 & Agree \\
2 & I found myself getting upset rather easily & 2.43 & Disagree \\
3 & I found it difficult to relax & 2.51 & Agree \\
4 & I found myself in situations that made me so anxious & 2.51 & Agree \\
5 & I felt I had nothing to look forward to & 2.56 & Agree \\
6 & I felt scared without any good reason & 2.41 & Disagree \\
7 & I felt sad and depressed & 2.47 & Disagree \\
8 & I felt that I had lost interest in just about everything & 2.52 & Agree \\
9 & I felt I wasn't worth much as a person & 2.48 & Disagree \\
10 & I felt that life wasn't worthwhile & 2.59 & Agree \\
\hline & Overall Weighted Mean & 2.52 & Agree \\
\hline
\end{tabular}

$\mathrm{N}=$ 240Legends: Strongly Disagree (1.00-1.75); Disagree (1.76-2.50); Agree (2.51-3.25); Strongly Agree (3.26-4.00)

Table 1 presents the top three highest weighted mean that was interpreted as agree. These indicators are: First: I couldn't seem to experience any positive feelings at all (2.70); Second: I felt that life wasn't worthwhile (2.59); Third: I felt I had nothing to look forward to (2.56). And also it has top three lowest weighted mean that was interpreted as disagree. These indicators are: First: I felt I wasn't worth much as a person (2.48); Second: I felt sad and depressed (2.47); Third: I found myself getting upset rather easily (2.43). The weighted mean is 2.52 which is described as agree. The results revealed that mostly students are experiencing stress but not in a high level of stress they were experiencing. Even the students experiencing stress, it doesn't affect their academics and their health. It also indicates that stress is universal which means that it also possible that the students are experiencing stress though they are in different situation and problems. But most likely the reason why students have stress is because of having pressure from the teachers and family. They even consider themselves stressed as they were more in achieving high expectations and the goal they want to achieve. It is also due to lacking of knowledge and idea on how to cope with stressors and consider them challenges. Students stress 
has connection to level of depressive symptoms when they have inability to cope up stress where it could weaken their development of resilience and having a vulnerability of depression (Sawatzky, Ratner, Richardon, Washblum, Sudmant and Mirwaldt, 2012).Coping stress management described as the thoughts and behaviors which is used to manage the internal and external needs and demands of the situations (Goodhand and Rampton, 2008). Furthermore, there are various coping strategies to use when an individual is coping stress which depends on the nature of situation, the personality of individual, and the interaction between the person and situation factors where it influences the choices and effectiveness of the way in coping (DeLongis and Holtzman, 2005)

\section{TABLE 2}

\section{Students' Attitude Towards Stress}

The table 2 shows the frequency and the percent of the students' attitude towards tress. The first illustration shows that "no stress at all" has 0 frequency and $0 \%$, while the "slightly stressed" has 27 and $11.20 \%$. The "fairly stressed" has 188 and has $78.30 \%$ and the "very stressed" has 25 and $10.40 \%$. The results revealed that $78.30 \%$ of the respondents have the feelings of being fairly stressed which means that they has stress but not as difficult situations that can affect to their studies. Even though some students says that they barely experiencing very stressed, it doesn't seem apply as a worst case for them because usually they can still manage their stress. And for those who answered slightly stressed, these respondents are more likely a happy go lucky because they didn't consider stress a hindrance to their goal in life. But among for those respondents, it is clearly that mostly respondents consider that they felt fairly stressed as it because of the different environment they experiencing. The environment also affect the understanding of the students as well as to their stressors because they didn't used to from the environment to the environment they used to. By rough estimation, the table reveals the normality of the number of respondents taken as sample of this study.

\begin{tabular}{ccc}
\hline Indicators & Frequency & Percent \\
\hline No stress at all (1-10) & 0 & $0 \%$ \\
Slightly stressed (11-20) & 27 & $11.20 \%$ \\
Fairly stressed (21-30) & 188 & $78.30 \%$ \\
Very stressed (31-40) & 25 & $10.40 \%$ \\
Total & 240 & $100 \%$ \\
\hline
\end{tabular}




\section{TABLE 3}

\section{Students' Cognitive Ability}

Indicator

1 Thinking is fun

2 The best to do is the things that could challenge my thinking abilities

3 I think hard as I could

4 Learning new ways of thinking is interesting and exciting

5 I'll make sure that I learn something and get my job done better

6 Complex problems is interesting than simple problems

7 I'm interested in handling situation that requires thought

8 I like giving thoughts to the tasks I've already learned

9 It is fun for making new situations in problems solving

1 I like life full of challenges I must solve
W. M. Interpretati

on

$\begin{array}{lc}2.69 & \text { Agree } \\ 2.48 & \text { Disagree }\end{array}$

2.55

2.53

2.49

2.66

2.65

2.76

2.80

2.75
Agree

Agree

Disagree

Agree

Agree

Agree

Agree

Agree

0

Overall Weighted Mean

2.64

Agree

$\mathrm{N}=240$ Legends: Strongly Disagree (1.00-1.75); Disagree (1.76-2.50); Agree (2.51-3.25); Strongly Agree (3.26-4.00)

The table 3 above shows the top three highest weighted mean interpreted as agree, which these are: First: It is fun for making new situations in problems solving (2.80); Second: I like giving thoughts to the tasks I've already learned (2.76); Third: I like life full of challenges I must solve (2.75). In contrast, there are only two lowest weighted mean interpreted as disagree, which these are: First: I'll make sure that I learn something and get my job done better (2.49); Second: The best to do is the things that could challenge my thinking abilities (2.48). The overall weighted mean is 2.64 which is interpreted as agree. This means that the students in Jagobiao National High School-Senior High recognize and understand their level and the capability to their cognitive ability. As they learn new knowledge and ideas in every lesson, it helps them to better understand the capability of their conscious mental ability. Conscious mental activity which are to understand, to learn, to analyze, to interpret, and to think are responsible why students know and can manage the difficulties in any situation. And since conscious mental activities are part of the cognitive ability, it instantly understood that ever since, students are more likely used and apply their cognitive ability in any situation even though they didn't know. Because cognitive ability is natural ability of a person that is already apply even though it didn't mean to apply as the same as the principle of respiratory circulation. Everyone can improve their cognitive ability which is important for success in any field (Halpern, 2004). Some test across academic and work settings has a strong predictor, but needs deeper understanding on the cognitive abilities development and evaluating more cognitive ability test (Kuncel and Hezlett, 2010). Cognitive ability is very essential in creating and sustaining high-achievement milieu that leads to economic growth and wealth, democratic, and free society (Rindermann and Thompson, 2011) 


\section{TABLE 4}

Students' Cognitive Ability

The table 4 shows the frequency and the percent of the students' cognitive ability. The first illustration shows that the "low cognitive ability" has 0 frequency and $0 \%$, the "fair cognitive ability" has 1 frequency and only have $0.40 \%$. The "moderately high in cognitive ability" have 222 and have $92.50 \%$, while the "high in cognitive ability" have 17 and only $7.10 \%$. This revealed that the highest frequency is moderately high in cognitive ability which means that mostly of the respondents had a moderately high in their cognitive ability. They consider their self that they better know their mental conscious ability (cognitive ability) as more they evaluate and understand deeper more about their development and growth in their cognitive area. There was only some respondents answered high cognitive ability which it means that it's rarely to students highly understand the maximum to used their cognitive ability and enhance the different cognitive area. By rough estimation, the table reveals the normality of the number of respondents taken as sample of this study.

TABLE 5

\begin{tabular}{ccc}
\hline Indicators & Frequency & Percent \\
\hline Low Cognitive Ability(1-10) & 0 & $0 \%$ \\
Fair Cognitive Ability (11-20) & 1 & $0.40 \%$ \\
Moderately High Cognitive Ability (21-30) & 222 & $92.50 \%$ \\
High Cognitive Ability (31-40) & 17 & $7.10 \%$ \\
Total & 240 & $100 \%$ \\
\hline
\end{tabular}

NCAE RESULTS

STUDENTS' SCIENTIFIC ABILITY

\begin{tabular}{lccc}
\hline & Value & Df & Asymp. Sig. (2-sided) \\
\hline Pearson Chi-Square & $11.801^{\mathrm{a}}$ & 6 & .067 \\
$\mathrm{~N}$ of Valid Cases & 240 & & \\
\hline
\end{tabular}

a. 8 cells $(66.7 \%)$ have expected count less than 5 . The minimum expected count is .00 .

In this table, the p-value (0.067) is greater than the significant alpha (0.05), $(p=0.068<0.05)$. Thus, there is no association of the students' cognitive ability questionnaire to their scientific ability. In other words, the given questionnaire is not bases to determine the ability of the students especially into their scientific ability. The cognitive ability questionnaire was only used to determine how students able to know or handle their cognitive ability. While the scientific ability determine by organizing way that agrees with the method and principles. Furthermore, the cognitive ability questionnaire was based in determining the understanding of the students to their cognitive ability while the scientific ability determines the capability in organizing the methods and principles. 
INTERNATIONAL JOURNAL OF ACADEMIC RESEARCH IN BUSINESS AND SOCIAL SCIENCES

Vol. 10, No. 4, April, 2020, E-ISSN: 2222-6990 @ 2020 HRMARS

Students' Verbal Abililty

\begin{tabular}{lccc}
\hline & Value & Df & Asymp. Sig. (2-sided) \\
\hline Pearson Chi-Square & $1.077^{\text {a }}$ & 4 & .898 \\
N of Valid Cases & 240 & & \\
\hline
\end{tabular}

a. 5 cells $(55.6 \%)$ have expected count less than 5 . The minimum expected count is .10 .

This table also shows that the p-value (0.898) is greater than the significant alpha (0.05), $(p=0.898<0.05)$. Hence, there is also no association between the verbal ability of the students and the cognitive ability questionnaire. The verbal ability of the students has no relationship to the cognitive ability questionnaire, thus, the cognitive ability questionnaire is more likely to determine in logic, analyze, systematic, deductive, and comprehensive approach while the verbal ability determines the students' capability in relating and consisting of words, spoken, and form from the structure of the words. Furthermore, even the verbal ability shows how students understand their cognitive ability, the cognitive ability questionnaire doesn't relate to the verbal ability.

Students' Mathematical Ability

\begin{tabular}{lccc}
\hline & Value & Df & Asymp. Sig. (2-sided) \\
\hline Pearson Chi-Square & $13.427^{\text {a }}$ & 4 & .009 \\
N of Valid Cases & 240 & & \\
\hline
\end{tabular}

a. 5 cells $(55.6 \%)$ have expected count less than 5 . The minimum expected count is .08 .

On the other hand, this table revels that the $p$-value $(0.009)$ is lesser than the significant alpha (0.05), $(p=0.009<0.05)$. Hence, there is an association between the mathematical ability of the students and to the cognitive ability questionnaire. Since the cognitive ability questionnaire focuses in logic, analyze, systematic, deductive, and comprehensive approach, the mathematical ability also to understand, analyze, interpret, and equate with some numerical equations. In other words, the mathematical ability and the cognitive ability questionnaire has a relationship to each other especially in determining and understanding the capability and view of the students to their cognitive ability. General cognitive ability and cognitive aptitude has a significant connection to the computational thinking but it has a lesser extent in inductive reasoning, spatial, and verbal abilities (Roman-Gonzales, Perez-Gonzales and Jimenez-Fernandez, 2016) 


\section{TABLE 6}

\section{Students' Cognitive Ability and Attitude Towards Stress}

In this table, the $p$-value $(0.068)$ is greater than the significant alpha (0.05), $(p=0.068<0.05)$. The decision is failed to reject the null hypothesis (Ho) which means, there is no significant relationship between the degree of students' attitude towards stress and the level of their cognitive ability. Students have a capability to understand and evaluate their cognitive ability which is significant when they are coping up their stress. Their conscious mental ability which are to understand, to analyze, to interpret, and to learn helps them in order to solve the problems and the situation. But the cognitive ability doesn't show a relationship to the attitude as it because, cognitive ability only helps to grow and develop the knowledge and the perspective a person. Even the students have great cognitive ability it doesn't mean that they are also have a great attitude in dealing stress. Most likely, attitude only helps the students to lessen their tension and nervous to cope up the stress, it signifies that attitude can only provide a support for in able the students to achieve or solve a problem or a situation. Students' stress is related to its level of depressive symptoms when it has inability to cope up even in a low level of stress that could weaken the development of resilience and having a vulnerability of depression (Sawatzky, Ratner, Richardson, Washbum, Sudmant and Mirwaldt, 2012). Though, attitude can still help to manage the stress by controlling the emotions and the self-perspective to the situation. The selfleadership and emotion regulation strategy in coping stress has a positive effects and self-efficacy (Houghton, Wu, Godwin, Neck and Manz, 2012). In contrast, when the attitude wouldn't able to handle the difficulties and the lacking of resources in order to cope up the stress, it can give a negative impact especially in coping stress which uses the cognitive ability. Lacking of material resources and psychological resources can give a harmful effect to them if they react emotionally and pressured in the environment (Michie, 2002).

\section{Summary of Findings, Conclusion, and Recommendation}

This chapter presents the summary, conclusions, and recommendation of this study on students' cognitive ability and attitude towards stress of the Jagobiao National High School-Senior High School department.

\begin{tabular}{lccc}
\hline & Value & Df & Asymp. Sig. (2-sided) \\
\hline Pearson Chi-Square & $8.740^{\mathrm{a}}$ & 4 & .068 \\
N of Valid Cases & 240 & & \\
\hline
\end{tabular}

a. 5 cells $(55.6 \%)$ have expected count less than 5 . The minimum expected count is .10 .

\section{Findings}

The students are more likely experiencing stress but in different manner, students are fairly stressed which they don't experiencing a stress that indicates for them as a threat in their academic field and to their health. Hence, students are capable to handle their attitude towards stress.

The students' level of their cognitive ability is more in moderately high cognitive ability which means that their mental conscious ability are in stage which they know how to handle 
them. This mental conscious ability are more likely to understand, analyze, interpret, and learn which at the same time is the age of their maturation where they know and learn about new things and experience.

This research study reveals that there is no association between the students' cognitive ability and attitude towards stress. The mental conscious ability is part of the individuals and this ability helps to cope with the stressors but doesn't help to the attitude towards stress. Cognitive ability cannot help to the attitude but it can provide supports in order to manage and solve the problems and situations.

\section{Conclusion}

Cognitive ability determines the credibility and the capability of the students especially to their analytical thinking, understanding comprehensive, interpreting, evaluating, and recognizing the problems or the situations upon on different circumstances. Unfortunately, cognitive ability doesn't help the attitude of the students in dealing stress, it only supports by managing stress of the students in creating and providing possible solutions in coping stress. The cognitive ability of the students in Jagobiao National High School specifically Senior High students helps them in providing a solutions in managing stress but doesn't help to their attitude towards stress. Attitude only provides the emotional aspect of the students which is the reason why the cognitive ability can only support in providing and helping to the emotional aspect because cognitive ability are more in intellectual aspect. In other words, the social cognitive theory of self-regulation talked about how people exert or act on their self-monitoring, self-observation, and selfperception that were categorized by their self - regulation as part to their cognitive ability (Bandura, 1991). Coping stress manage the thoughts and behaviors that are used to manage the internal and external needed or demands of the situation (Goodhand and Rampton, 2008). Hence, cognitive ability addressed the behavior under stress and in emergencies or other abnormal situations on how do students subsequently react or perform but not to their attitude towards stress. Coping stress manage the thoughts and behaviors that are used to manage the internal and external needed or demands of the situation (Goodhand and Rampton, 2008).

The researchers conclude that, the study support to the students, teachers, and future researchers that the cognitive ability not necessary determines the attitude towards stress. When it comes in dealing stress, Cognitive ability helps and provides information and approaches while it's only support when it comes in attitude towards stress. By doing so, other school departments, campuses and universities knows how to deal the attitude of their students and to determine on how to develop the cognitive ability without affecting the attitudes. Furthermore, the researchers still need more time and researches in order to support greatly this study can provide a possible solution in cognitive ability and managing stress without or within affects the attitude.

\section{Recommendations}

The following are the recommendations of the researcher based on the gather data:

1. Students must think positive about life so that they won't be lured in negative thoughts and actions.

2. Implement some school activities that can help to the students cope with their stress. 
3. Teachers should help the students when they're need help also to their cognitive ability without giving them a lot of stress.

4. Parents should support their children in time of unfavorable situation so that their children will lessen their thoughts into negativities.

\section{References}

Abel, M. H. (2002). Humor, stress, and coping strategies. Humor. 15(4), 365-381. https://dx.doi.org/0933-1719/02/0015-0365

Bandura, A. (2000). Social cognitive theory of self-regulation. Organizational Behavior and Human Decision Processes. 50, 248-287. https://dx.doi.org/0749-5978/91

Busato, V. V., Prins, F. J., Elshout, J. J., \& Hamaker, C. (2000). Intellectual ability, learning style, personality, achievement motivation and academic success of psychological students in higher education. Personality and Individual Differences. 29, 1057-1068. https://dx.doi.org/S0191-8869(99)00253-6

Casey, B. J., Tottenham, N., Liston, C., \& Durston, S. (2005). Imaging the developing brain: What Have We Learned About Cognitive Development? Trends in Cognitive Sciences. 9(3), 104-109. https://dx.doi.org/10.1016/j.tics.2005.01.011

Chiese, F., \& Primi, C. (2010). Cognitive and non-cognitive factors related to students' statistics achievement. Statistics Educational Research Journal. 9(1), 6-26.

DeLongis, A., \& Holtman, S. (2005). Coping in context: The Role of Stress, Social Support, and Personality in Coping. Journal of Personality. 73(6), 1-24. https://dx.doi.org/10.1111/j.1467- 6494.2005.00361.x

Furnham, A., Chamorro-Premuzic, T., \& McDougall, F. (2003). Personality, cognitive ability, and beliefs about intelligence as predictors of academic performances. Learning and Individual Differences. 14, 49-66. https://dx.doi.org/10.1016/j.lindif.2003.08.002

George, D. R., Dellasera, C., Whitehead, M. M., \& Bordon, A. (2013). Facebook-based stress management resources for first-year medical students: A Multi-Method Evaluation. Computers in Human Behavior. 29, 559-562. https://dx.doi.org/10.1016/j.chb.2012.12.008

Giga, S. I., Cooper, C. L., \& Faragher, B. (2003). The development of a framework for a comprehensive approach to stress management interventions at work. International Journal of Stress Management. 10(4), 280-296. https://dx.doi.org/10.1037/10725245.10.4.280

Goodhand, J., \& Rampton, D. (2008). Psychological stress and coping in IBD. Gut. 57, 13451347. https://dx.doi.org/10.1136/gut.2008.15422

Halpern, D. F. (2004). A cognitive-process taxonomy for sex differences in cognitive abilities. American Psychological Society. 13(4), 135-139.

Haraldsson, K. S., Lindgren, E. M., Fridlund, B. G. A., Baigi, A. M. A. E., Lydell, M. C., \& Marklund, B. R. G. (2008). Evaluation of a school-based health promotion programme for adolescents aged 12-15 years with focus on well-being related to stress. Public Health. 122, 25-33. https://dx.doi.org/10.1016/j.puhe.2007.04.016 
Houghton, J. D., Wu, J., Godwin, J. L., Neck, C. P., \& Manz, C. C. (2012). Effective stress management: A Model of Emotional Intelligence, Self-Leadership, and Student Stress Coping. Journal of Management Education. 36(2), 220-238. https://dx.doi.org/10.1177/1052562911430205

Hodson, G., \& Busseri, M. A. (2012). Bright minds and dark attitudes: Lower Cognitive Ability Predicts Greater Prejudice Through Right-Wing Ideology and Low Intergroup Contact. Psychological Science. 23(2), 187-195. https://dx.doi.org/10.1177/0956797611421206

Koenig, K. A., Frey, M. C., \& Detterman, D. K. (2008). ACT and general cognitive ability. Intelligence. 36, 153-160. https://dx.doi.org/10.1016/j.intell..2007.03.005

Kuncel, N. R., \& Hezlett, S. A. (2010). Fact and fiction in cognitive ability testing for admissions and hiring decisions. Current Directions in Psychological Science. 19(6), 339-345. https://dx.doi.org/10.1177/0963721410389459

Labbe, E., Schmidt, N., \& Babin, J. (2007). Coping with stress: The Effectiveness of Different Types of Music. Appl Psychological Biofeedback. 32, 163-168. https://dx.doi.org/10.1007/s10484-007-9043-9

Lubinski, D. (2009). Exceptional cognitive ability: The Phenotype. Behav Genet. 39, 350- 358. https://dx.doi.org/10.1007/s10519-009-9273-0

Matud, M. P. (2004). Gender differences in stress and coping styles. Personality and Individual Differences. 37, 1401-1415. https://dx.doi.org/10.1016/j.2004.01.010

Michie, S. (2002). Causes and management of stress at work. Occup Environ Med. 59, 67-72.

Murphy, R. J., Gray, S. A., Sterling, G., Reeves, K., \& DuCette, J. (2009). A comparative study of professional student stress. Journal of Dental Education. 73(3), 328-337.

Ready, D. D. (2010). Socioeconomic disadvantage, school attendance, and early cognitive development: The Differential Effects of School Exposure. American Sociological Association. 83(4), 271-286. https://dx.doi.org/10.1177/003804/0710383520

Redwood, S. K., \& Pollak, M. H. (2007). Student-led stress management program for first-year medical students. Teaching and Learning in Medicine. 19(1), 42-46.

Rinderman, H. (2012). African cognitive ability: Research, Results, Divergences, and Recommendations. Personality and Individual Differences. 55(3), 229-233. https://dx.doi.org/10.1016/j.paid.2012.06.022

Rinderman H., Thompson J. (2011). Cognitive capitalism: The Effect of Cognitive Ability on Wealth, as Mediated Through Scientific Achievement and Economic Freedom. Psychological Science. 1-10. https://dx.doi.org/10.1177/0956797611407207

Roman-Gonzales M., Perez-Gonzales J.-C., \& Jimenez-Fernandez C. (2016). Which cognitive abilities underlie computational thinking? Criterion validity of the computational thinking test. Computers in Human Behavior. 72, 1-14. https://dx.doi.org/10.1016/j.chb.2016.08.047

Rudasill, K. M., Adelson, J. J., Callahan, C. M., Houlihan, D. V., \& Keizer, B. M. (2013). Gifted students' perceptions of parenting styles: Associations With Cognitive Ability, Sex, Race, and Age. Gifted Child Quarterly. 57(1), 15-24. https://dx.doi.org/10.1177/0016986212460886 
Sawatzky, R. G., Ratner, P. A., Richardson, C. G., Washbum, C., Sudmant, W., \& Mirwaldt, P. (2012). Stress and depression in students. Nursing Research. 61(1), 13-21. https://dx.doi.org/10.1097/NNR.0b013e31823b1440

Souza, B. C., De Lima e Silva, L. X., \& Roazzi, A. (2010). MMORPGS and cognitive performance: A Study With 1280 Brazilian High School Students. Computer in Human Behavior. 26, 1564-1573. https://dx.doi.org/10.1016/j.chb.2010.06.001

Varvogli, L., \& Darviri, C. (2011). Stress management techniques: Evidence-Based Procedures that Reduce Stress and Promote Health. Health Science Journal. 5(2), 74-89.

Williams, R. A., Gatien, G., \& Hagerty, B. (2011). Design element alternatives for stressmanagement intervention websites. Nurs Outlook. 59, 286-291. https://dx.doi.org/10.1016/j.outlook.2011.03.009 